\title{
A STUDY OF RADON EMANATION FROM BUILDING MATERIALS USING SOLID STATE NUCLEAR TRACK DETECTORS CR-39
}

\section{Anwar Khadher Mohammed ${ }^{1, *}$, M. I. Ahmed ${ }^{2}$}

${ }^{1}$ Department of Physics, Faculty of Education, Yafea, Aden University, Yemen

${ }^{2}$ Department of Physics, Faculty of Education, Zinjiebar, Abyan University, Yemen

*Corresponding author; Anwar Khadher Mohammed; E-mail: anwarhdr@gmail.com

HNSJ, 2022, 3(2); https://doi.org/10.53796/hnsj3222

\section{Published at 01/02/2022}

\section{Accepted at 25/01/2022}

\begin{abstract}
In this study the radon and radium concentration, surface and mass exhalation rates, annual effective dose and alpha index for 20 of building material samples frequently used in Aden governorate, Yemen were measured. The can technique, containing CR-39, was used. The radon concentration activity of the samples was found to vary from 50.71 to $525 \mathrm{~Bq} \mathrm{~m}^{-3}$ with an average of $163.26 \mathrm{~Bq} \mathrm{~m}^{-3}$. The radium concentration varied from 0.26 to $1.92 \mathrm{~Bq} \mathrm{~kg}^{-1}$, with an average of $0.67 \mathrm{~Bq} \mathrm{~kg}{ }^{-1}$, The mass exhalation rates were found to vary from 1.95 to $14.5 \mathrm{mBq} \mathrm{kg}^{-1} \mathrm{~h}^{-1}$, with an average of $5.03 \mathrm{mBq} \mathrm{kg}^{-1} \mathrm{~h}^{-1}$, while the surface inhalation rates varied from 35.58 to $376 \mathrm{mBq}$ $\mathrm{m}^{-2} \mathrm{~h}^{-1}$, with an average of $115.59 \mathrm{mBq} \mathrm{m} \mathrm{m}^{-2} \mathrm{~h}^{-1}$. The annual effective doses due to indoor uses varied from 1.42 to $14.77 \mathrm{mSv} \mathrm{y}^{-1}$, with an average of $4.58 \mathrm{mSv} \mathrm{y}^{-1}$. The alpha index was found to vary from 0.0017 to $0.0096 \mathrm{~Bq} \mathrm{~kg}^{-1}$, with an average of $0.0033 \mathrm{~Bq} \mathrm{~kg}^{-1}$. The results of this study show that the values obtained for all samples were within the internationally accepted recommended values. Therefore, these samples can be used as building materials as they do not pose a major risk to humans.
\end{abstract}

Key Words: Radon exhalation rate, CR-39, Can technique, Building materials, Annual effective dose. 


\section{دراسة انبعاث الرادون هن هواد البناء باستغدام كواشف المسارات النووية الصلبة الصبة}

انور خضر محمد بلر 1,", محمود عيسى احمد2

1قسم الفيزياء, كلية التربية يافع, جامعة عدن, عدن, اليمن

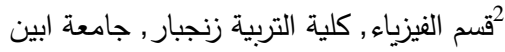
الباحث الممثل: انور خضر محمد بدر؛ البريد الالكتروني: anwarhdr@gmail.com

HNSJ, 2022, 3(2); https://doi.org/10.53796/hnsj3222

$$
\text { تاريخ القبول: 2022/01/25م }
$$

تاريخ النشر: 2022/02/01م

\section{المستخلص}

في هذه الدراسة قمنا بقياس تراكيز الرادون والراديوم وكذا قياس نسبة الانبعاث السطحي والكتلي للرادون والجرعة الفعالة السنوية ودليل الفا لعشرين عينة من مواد البناء المختلفة المستخدمة في محافظة عدن, الجمهورية اليمنية. باستخدام تقنية العلب المغلقة التي تحتوي على كاشف المسار النووي CR-39. وقد وجد أن تركيز غاز الرادون يتراوح في العينات ما بين 50.71 Bq m إلى موس 525 Bq m mBq kg-1 0.67 kg وكذلك الانبعاث الكتلي يتراوح ما بين 14.5 mBq kg-1 h 1.95 mBq kg

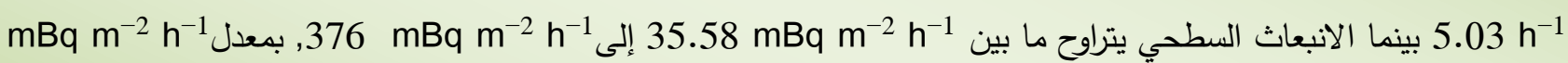

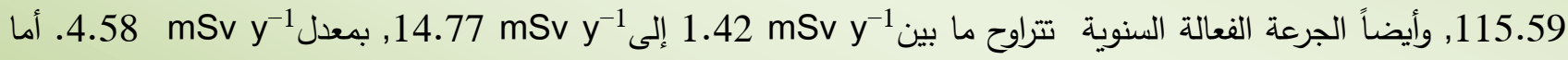
دليل الفا فيتراوح ما بين تثبت أن كل القيم الحاصل عليها تقع ضمن القيم الموصى بها والمقبولة عالمياً. لذا فإن هذه العينات يمكن أن تستخدم كمواد بناء ولا تشكل خطراً كبيراً على الإنسان. الكلمات المفتاحية: نسبة انبعاث الرادون, كاثف الاثر CR-39 , تقنية العلبة المغلقة , مو اد البناء, الجرعة الفعالة 


\section{1- INTRODUCTION}

Scientists consider the process of the measurement of radon exhalation rates from building materials were becoming of a great interest as long as exposure levels to the populations is a disturbing problem. More than $40 \%$ of the activities take place indoors, and more than $40 \%$ of the background radiation is coming from radon and its daughters. The main source of radon in air inside dwellings is due to the emanation from building materials [1].

Radon is a colorless, odorless, tasteless, non-flammable and $\alpha$-radioactive gas. Therefore it cannot be detected with human senses. Its melting point is $-70{ }^{\circ} \mathrm{C}$ and boiling point is $-60.8{ }^{\circ} \mathrm{C}$. Radon has the highest gas density of $\sim 9.96 \mathrm{~kg} . \mathrm{m}^{-3}$ and is about seven times heavier than air. Being a noble gas, it has greater ability to migrate freely through soil, air, etc. [2]. Radon is a naturally occurring radioactive gas that is formed by the decay of radium. Radon is found in all types of rocks, soils and building materials. Among all isotopes of radon, ${ }^{222} \mathrm{Rn}$, with a half-life of 3.8 days, is considered the predominant hazardous radionuclide. Prolonged exposure to radon may increase the risk of lung cancer [3].

Uranium and radium are the two elements that form building materials made from stone and sand, and they generate radon. Many of these materials, such as brick, wallboard or concrete are sufficiently porous to allow the radon to escape into the air. The diffusion of ${ }^{222} \mathrm{Rn}$ from building material is influenced by moisture content of the material, density, the presence of sealants, the material itself and the nature of the substances with which it is mixed [4]. The International Commission for Radiological Protection has suggested that areas where 1\% or more of the building have indoor radon concentration higher than the 10 times of national average should be considered as "radon prone" areas. The radon concentration value ranges of 500-1500 and 200-600 $\mathrm{Bq} \mathrm{m}^{-3}$ for work places and dwellings, respectively, are also recommended; those concentrations do not pose a significant risk for workers and populations [5].

It is perhaps difficult and expensive to study the radon emanation from building materials by using electronic equipment; because the low level of emanation from the material long term measurements are essential and very few can be made in a reasonable time, so the method based on the use of solid state nuclear tracks detectors (SSNTD) is probably the most widely applied for long term radon measurements [6].

In the present study, the Can-technique was used to measure the radon concentration, the radium contents, exhalation rates of radon, the annual effective dose and the alpha index of some building materials used locally in Aden governorate, Yemen.

\section{2- MATERIALS AND METHODS}

Twenty building material samples were collected from customarily used building materials available on the market, randomly taken from housing locations, other buildings that are under construction, and from building material suppliers in Aden governorate, Yemen in March 2021. The customarily used building materials include marble, granite, brick, block, concrete and gypsum, as shown in Table(1). Solid samples were crushed and milled to a fine powder with uniform particle size; powder samples were used in their natural forms. All samples were dried in a temperature controlled furnace (oven) at a temperature $130{ }^{\circ} \mathrm{C}$ for $2 \mathrm{hrs}$ to ensure that moisture was complete. An amount of 70-120 grams of each samples was taken, each sample was placed at the bottom of a plastic can (height $=11$ $\mathrm{cm}$, diameter $=7 \mathrm{~cm}$ ), as shown figure (1). A passive method (can technique) using SSNTDs for measurements of radon parameters was used. A piece of CR-39 detector of size $(1.5 \mathrm{~cm} \times 1.5 \mathrm{~cm} \times$ $0.650 \mathrm{~mm}$ ) was fixed on the top of inner surface of the can, in such a way that its sensitive surface always facing the sample. The can was sealed air tight with adhesive tape and kept for assessment of radon exhalation for exposure evaluation over three months. During the exposure period, the detector was exposed freely to the emergent radon from the sample in the can so that it could record alpha particles resulting from the decay of radon in the remaining volume of the can. After that, the detectors were separated from the sample cup, collected and chemically etched in a $30 \%$ solution of $\mathrm{KOH}$, at $70.0 \pm 0.10{ }^{\circ} \mathrm{C}$ for a period of $7 \mathrm{hrs}$. The resulting tracks were counted under an optical microscope of magnification 400x [7]. 


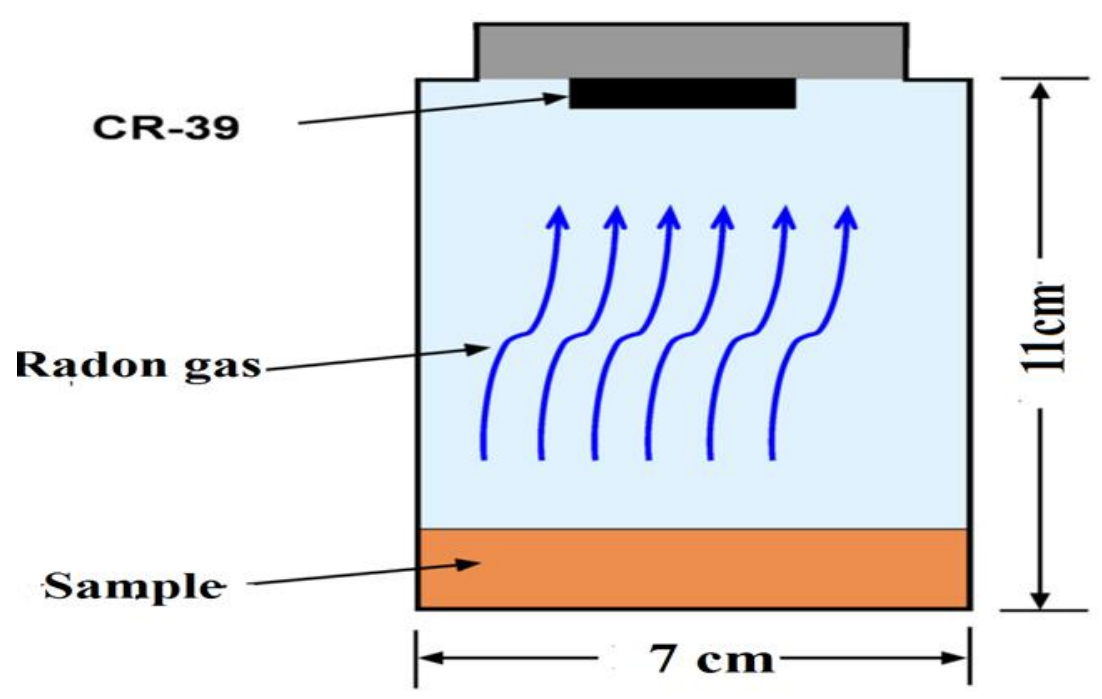

Figure (1). Schematic diagram of the sealed-can technique

\section{3- THEORETICAL CONSIDERATIONS}

\section{1- Radon concentration}

The activity concentration of radon gas in the different samples is calculated in $\mathrm{Bq} \mathrm{m}^{-3}$ by the following equation:

$$
C_{R n}=\frac{\rho_{R n}}{k_{R n} t}
$$

Where $\mathrm{C}_{\mathrm{Rn}}$ activity radon concentration $\left(\mathrm{Bq} \mathrm{m}^{-3}\right), \rho_{R n}$ is the track density (tracks per $\left.\mathrm{cm}^{2}\right), \mathrm{K}_{\mathrm{Rn}}$ is the calibration constant which was previously determined to be 0.16 tracks $\mathrm{cm}^{-2}$ day $\left.^{-1}(\mathrm{~Bq} \mathrm{~m})^{-3}\right)^{-1}$ with an uncertainty of about $\pm 17 \%$, and $t$ is the exposure time $[6,8]$.

3.2- Radium concentration

The radium concentration in collected samples was calculated in $\mathrm{Bq} \mathrm{kg}{ }^{-1}$ by the following equation [7]:

$$
C_{R a}=\frac{\rho_{R n} h A}{k T_{e} M}
$$

Where: $\mathrm{C}_{\mathrm{Ra}}$ is the effective radium content of sample in $\mathrm{Bq} \mathrm{kg}^{-1}, \mathrm{~h}$ is the height of CR-39 detector above the surface of sample in (m), A is the surface area of sample which exhaled the radon gas in $\left(\mathrm{m}^{2}\right), \mathrm{M}$ is the mass of sample in $\mathrm{kg}$ and $\mathrm{T}_{\mathrm{e}}$ is the effective exposure time which is calculated by the following equation:

$$
T_{e}=t-\frac{1}{\lambda\left(1-e^{-\lambda t}\right)}
$$

where here $\mathrm{t}$ is the exposure time $(\mathrm{h})$ and $\lambda\left(\lambda=7.55 \times 10^{-3} \mathrm{~h}^{-1}\right)$ is the radon decay constant $\quad\left(\mathrm{h}^{-1}\right)$.

\section{3- The exhalation rates of radon}

The surface $E_{A}$ and mass $E_{M}$ exhalation rates of radon are calculated using the following equations [6]:

$$
E_{A}=\frac{\lambda V C}{A T_{e}}
$$




$$
E_{M}=\frac{\lambda V C}{M T_{e}}
$$

Where $\mathrm{C}$ is the integrated radon exposure as measured by CR-39 plastic track detector $\quad\left(\mathrm{Bq} \mathrm{m}^{-3} \mathrm{~h}\right)$, $\mathrm{V}$ is the hollow volume $\mathrm{m}^{3}$.

3.4- The annual effective dose (AED)

The annual effective dose equivalent, $\mathrm{E}_{\mathrm{Eff}}$, was related to the average radon concentration $\mathrm{C}_{\mathrm{Rn}}$ by equation:

$$
E_{E f f}\left(W L M \cdot y^{-1}\right)=\frac{8760 \times n \times F \times C_{R n}}{170 \times 3700}
$$

Where: $\mathrm{n}$ is the fraction of time spent indoors, $\mathrm{F}$ is the equilibrium factor, 8760 is the number of hours per year, and 170 is the number of hours per working month. The values of $n=0.8$ and $F=0.4$ were used to calculate $E_{\text {Eff. }}$ For radon exposure, the effective dose equivalents were estimated by using a conversion factor of $6.3 \mathrm{mSv} \cdot \mathrm{WLM}^{-1}[9,10]$.

3.5- Alpha index

Several indexes dealing with the assessment of the excess $\alpha$-radiation due to the radon inhalation originating from the building materials (called "alpha-indexes") have been developed. In the present work, the alpha-indexes were determined through the following formula [6]:

$$
I_{\alpha}=C_{R a} / 200 B q g^{-1}
$$

The recommended exemption and recommended upper levels of ${ }^{226} \mathrm{Ra}$ concentrations in building materials are $100 \mathrm{~Bq} \mathrm{~kg}^{-1}$ and $200 \mathrm{~Bq} \mathrm{~kg}^{-1}$. When the ${ }^{226} \mathrm{Ra}$ activity concentration of a building material exceeds the value of $200 \mathrm{~Bq} \mathrm{~kg}^{-1}$, it is possible that the radon exhalation from this material could cause indoor radon concentrations exceeding $200 \mathrm{Bqm}^{-3}$ [11]. On the contrary, when its value is below $100 \mathrm{~Bq} \mathrm{~kg}^{-1}$, it is unlikely that the radon exhalation from the building materials could cause indoor radon concentrations exceeding $200 \mathrm{Bqm}^{-3}$ [12]. These considerations are reflected in the alpha index. The recommended limit concentration of ${ }^{226} \mathrm{Ra}$ is $200 \mathrm{~Bq} \mathrm{~kg}^{-1}$, for which $\mathrm{I}_{\alpha}=1$ [6].

\section{4- RESULTS AND DISCUSSION}

Table (1) shows the measured radon activity concentrations, the surface and mass exhalation rates, the radium equivalent contents, the annual effective dose equivalents and alpha index. Figure (2) shows the correlation between the radium and the radon concentrations, which equals 0.96; this result shows a good linear relationship. Table (2) reveals the measured radon concentration in the collected samples, where the radon concentration varies from 50.71 to $525 \mathrm{~Bq} \mathrm{~m}^{-3}$ with an average value 163.26 $\mathrm{Bq} \mathrm{m}^{-3}$. The results indicated that the highest level of radon concentration was in gravel, whereas the lowest was in Portland cement 2 . The values of radon concentrations were lower than the range of action levels from 200 to $600 \mathrm{~Bq} \mathrm{~m}^{-3}$ recommended by (ICRP, 1994) [13].

Table (1) shows the radium concentration in collected samples; where the radium concentration varies from 0.26 to $1.92 \mathrm{~Bq} \mathrm{~kg}^{-1}$ with an average value $0.67 \mathrm{~Bq} \mathrm{~kg}^{-1}$. The results indicated that the highest level of radium concentration was in gravel, whereas the lowest concentration of radium was Portland cement 2. The values of radium concentration were found to be less than the permissible value of $370 \mathrm{~Bq} \mathrm{~kg}$ as recommended by Organization for Economic Co-operation Development (OECD) and United Nation Scientific Committee on the Effects of Atomic Radiation (UNSCEAR) $[10,14]$. 
Table (1). Radon concentrations $C_{R n}$, radium contents $C_{R a}$, surface $E_{A}$ and $E_{M}$ mass exhalation rates, annual effective doses (AED) and alpha index $\left(\mathrm{I}_{\alpha}\right)$ for the different building material samples.

\begin{tabular}{|l|l|l|l|l|l|l|l|l|}
\hline No. & $\begin{array}{l}\text { Type of } \\
\text { building } \\
\text { material }\end{array}$ & $\begin{array}{r}\text { Country } \\
\text { of origin }\end{array}$ & $\begin{array}{l}\mathrm{C}_{\mathrm{Rn}} \\
\left(\mathrm{Bq} \mathrm{m}^{-3}\right)\end{array}$ & $\begin{array}{r}\mathrm{C}_{\mathrm{Ra}} \\
\left(\mathrm{Bq}^{-}\right)\end{array}$ & $\begin{array}{r}\mathrm{E}_{\mathrm{A}}(\mathrm{mBq} \\
\left.\mathrm{m}^{-3} \mathrm{~h}^{-1}\right)\end{array}$ & $\begin{array}{r}\mathrm{E}_{\mathrm{M}} \\
\left(\mathrm{mBq} \mathrm{Kg}^{-1} \mathrm{~h}^{-1}\right.\end{array}$ & $\begin{array}{r}\mathrm{AED} \\
\left(\mu \mathrm{Sv}^{-1}\right)\end{array}$ & $\begin{array}{r}\mathrm{I}_{\alpha} \\
\mathrm{Bq} \mathrm{Kg}^{-1}\end{array}$ \\
\hline $\begin{array}{l}\text { Cortland } \\
\text { Cement 1 }\end{array}$ & $\begin{array}{l}\text { Lortland } \\
\text { Cement 2 }\end{array}$ & Local & 70.75 & 0.36 & 49.64 & 2.73 & 1.99 & 0.0018 \\
\hline 3 & $\begin{array}{l}\text { Portland } \\
\text { Cement3 }\end{array}$ & Egypt & 115.56 & 0.60 & 82.83 & 4.55 & 3.24 & 0.0030 \\
\hline 4 & $\begin{array}{l}\text { Portland } \\
\text { Cement 4 }\end{array}$ & Saudi & 91.98 & 0.48 & 65.92 & 3.62 & 2.58 & 0.0023 \\
\hline 5 & White Cement & Saudi & 60.14 & 0.30 & 41.74 & 2.29 & 1.69 & 0.0015 \\
\hline 6 & Red Brick & Local & 79.01 & 0.41 & 56.03 & 3.08 & 2.22 & 0.0020 \\
\hline 7 & Red Brick & Saudi & 58.96 & 0.27 & 42.26 & 2.03 & 1.66 & 0.0013 \\
\hline 8 & Cement block & Local & 228.77 & 1.04 & 163.96 & 7.88 & 6.42 & 0.0052 \\
\hline 9 & Plaster & Local & 306.60 & 1.37 & 215.12 & 10.34 & 8.61 & 0.006 \\
\hline 10 & Concrete & Local & 193.39 & 0.88 & 138.61 & 6.66 & 5.43 & 0.0044 \\
\hline 11 & Ceramic & Egypt & 79.01 & 0.28 & 54.84 & 2.11 & 2.22 & 0.0013 \\
\hline 12 & Ceramic & India & 136.79 & 0.62 & 97.01 & 4.66 & 3.84 & 0.0030 \\
\hline 13 & Ceramic Glue & Saudi & 101.41 & 0.36 & 70.39 & 2.71 & 2.85 & 0.0017 \\
\hline 14 & Black Stones & Local & 80.19 & 0.29 & 57.47 & 2.21 & 2.25 & 0.0014 \\
\hline 15 & Garnish Stone & Local & 86.08 & 0.26 & 61.05 & 1.96 & 2.42 & 0.0012 \\
\hline 16 & Gravels & Local & 525.93 & 1.92 & 376.94 & 14.50 & 14.77 & 0.0096 \\
\hline 17 & Marble & China & 510.60 & 1.84 & 362.10 & 13.93 & 14.34 & 0.0092 \\
\hline 18 & Gypsum & Saudi & 77.83 & 0.39 & 54.02 & 2.97 & 2.19 & 0.0019 \\
\hline 19 & Brown Sand & Local & 332.54 & 0.98 & 230.81 & 7.40 & 9.34 & 0.0049 \\
\hline 20 & Wall Paint & Local & 79.01 & 0.40 & 55.43 & 3.05 & 2.22 & 0.0020 \\
\hline & & & & & & & \\
\hline
\end{tabular}

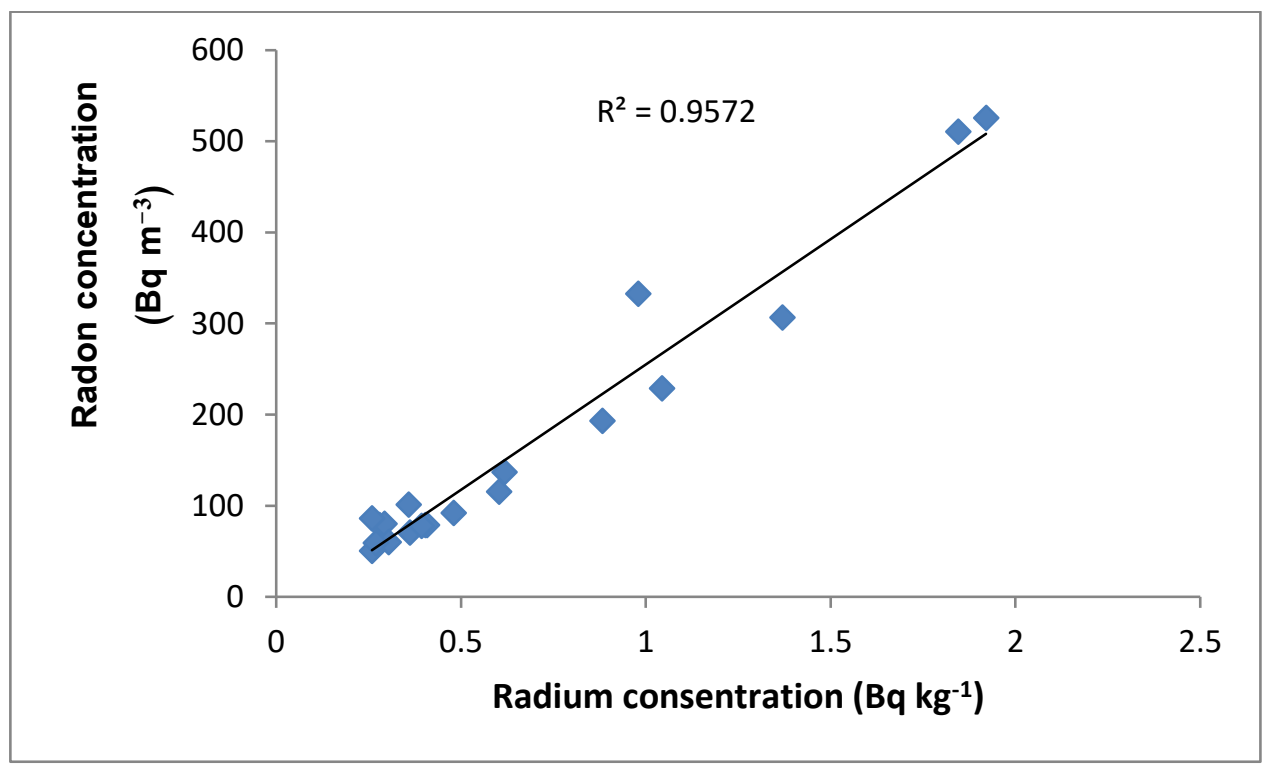

Figure (2). The correlation between radium concentration and radon concentration

Figures (3) and (4) show the correlation between the radium concentration and the exhalation rates of radon. A direct linear relation was observed between the radium concentration from one side, and the mass and surface exhalation rates in different samples in the studied area from the other side, which equal 1 and 0.97 , respectively.

Table (1) shows the mass and surface exhalation rates of radon. The mass exhalation rates were found to vary from 1.95 to $14.50 \mathrm{mBq} \mathrm{kg} \mathrm{h}^{-1}$ with an average value $5.03 \mathrm{mBq} \mathrm{kg}^{-1} \mathrm{~h}^{-1}$, while the surface exhalation rates varied from 35.58 to $376.94 \mathrm{~m} \mathrm{~Bq} \mathrm{~m}^{-2} \mathrm{~h}^{-1}$ with an average value $115.59 \mathrm{mBq} \mathrm{m}^{-2} \mathrm{~h}^{-1}$. 
The results showed that the highest values of radon's mass and surface exhalation rates were in gravel, whereas the lowest values were in Portland cement 2. The radon exhalation in studied samples was found to be below the average world value of $57600 \mathrm{mBq} \mathrm{m}^{-2} \mathrm{~h}^{-1}[15]$.

The annual effective doses for samples yielded values of $\left(1.42-14.77 \mu \mathrm{Sv} \mathrm{y}^{-1}\right)$ with a mean value of $4.58 \mu \mathrm{Sv} \mathrm{y}^{-1}$. The lowest values of the annual effective dose were Portland cement 2 while the highest dose came from gravel. The results obtained were below the standard limits ( $\left.1-5 \mathrm{mS} \mathrm{y}^{-1}\right)$ (National Council for Radiation Protection and Measurements [NCRP], 1987, 2017; UNSCEAR, 2000) [10, 16, 17].

Alpha-indexes of the samples were given in Table (1) (I $\alpha$ ) ranged from 0.0017 to $0.0096 \mathrm{~Bq} \mathrm{~kg}^{-1}$ with a mean value of 0.0033 for building materials used. All the samples measured showed values below the recommended upper level. These observed values were much less than unity showing that construction materials from this region cannot produce dangerous levels of indoor radon when used as building materials.

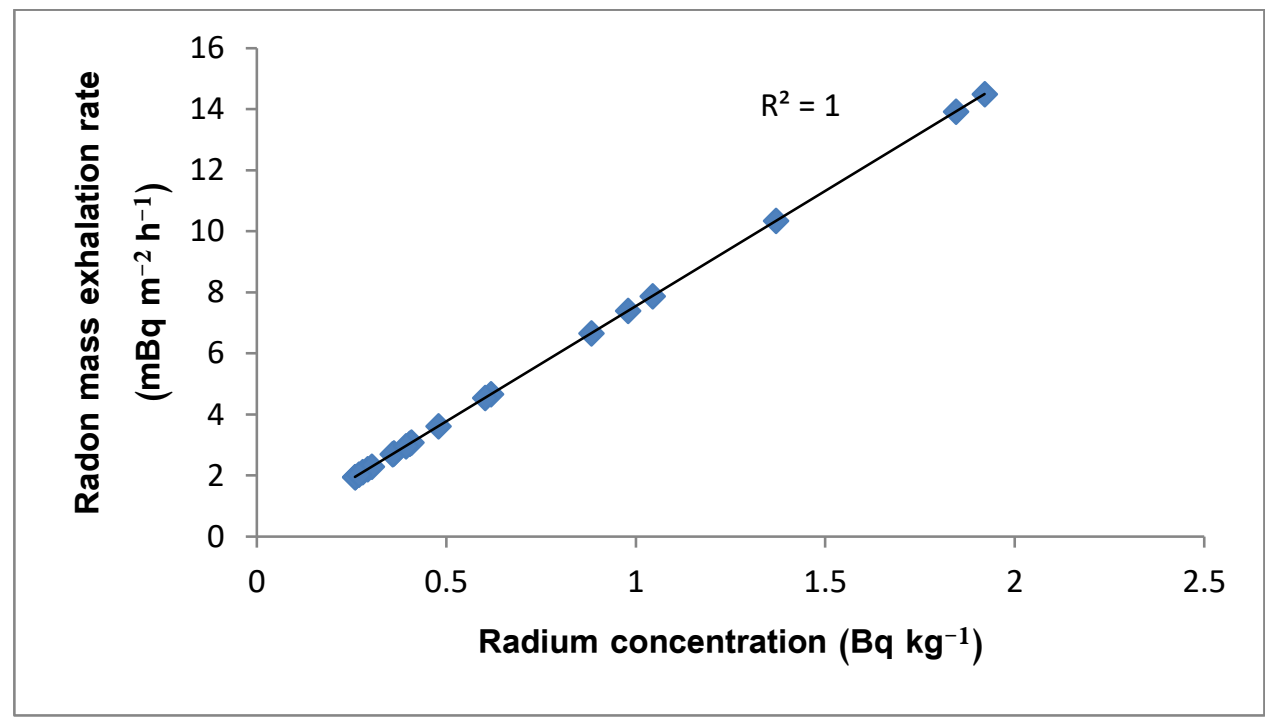

Figure (3). The correlation between radium concentration and mass exhalation rate

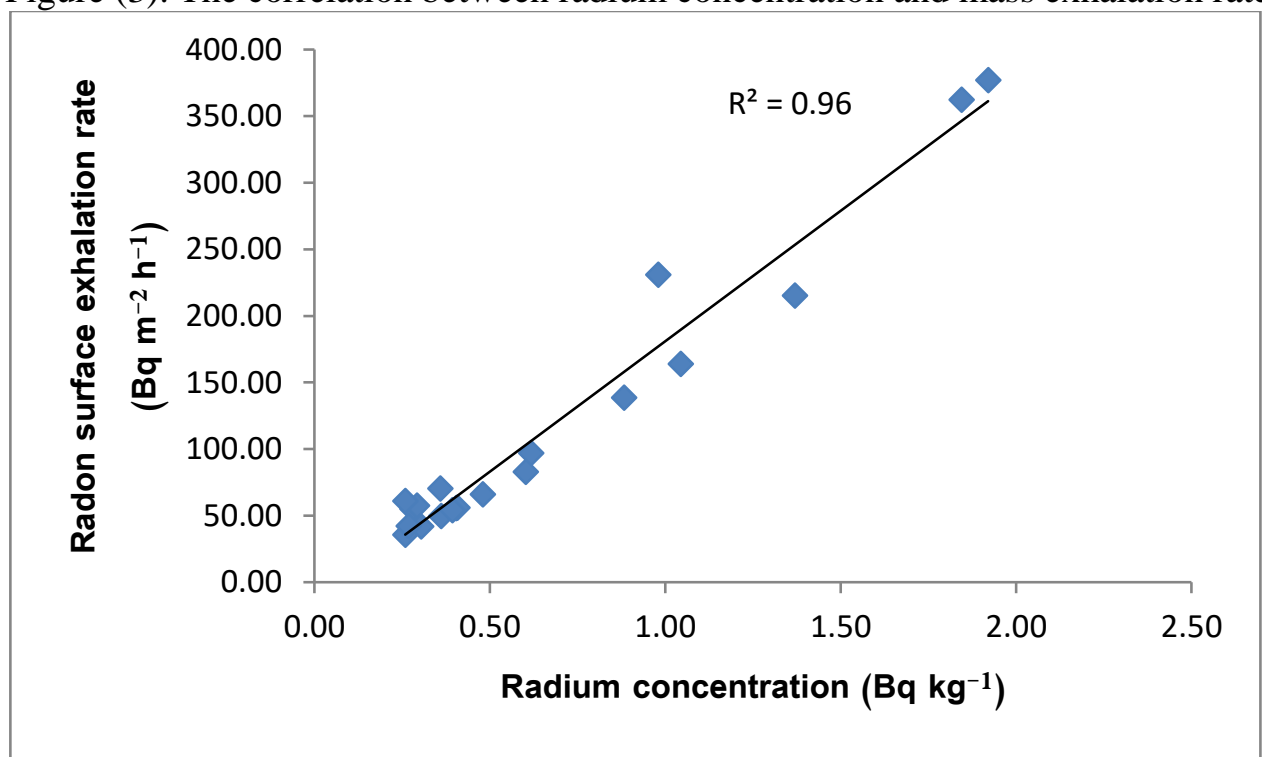

Figure(4). The correlation between radium concentration and surface exhalation rate.

For the sake of comparison, the recorded values of the radon concentration $\mathrm{Bq} \mathrm{m}^{-3}$, radon surface exhalation rate $\left(\mathrm{Bq} \mathrm{m}^{-2} \mathrm{~h}^{-1}\right)$ and the annual effective dose $\left(\mathrm{mSv} \mathrm{y}^{-1}\right)$ in the building material samples with those obtained in other parts of the world are exhibited in Table (2). Some of the results obtained in the present study are within the international values measured in many countries, while most of the results are higher. 
Table (2). Comparison between radon concentration $\left(\mathrm{C}_{\mathrm{Rn}}\right)$ surface exhalation rates $\left(\mathrm{E}_{\mathrm{A}}\right)$ and annual effective dose (AED) of some building materials in different countries.

\begin{tabular}{|c|c|c|c|c|c|}
\hline Material & country & $\mathrm{C}_{\mathrm{Rn}}\left(\mathrm{Bq} \mathrm{m}^{-3}\right)$ & $\begin{array}{l}\mathrm{E}_{\mathrm{A}} \quad(\mathrm{mBq} \\
\left.\mathrm{m}^{-2} \mathrm{~h}^{-1}\right)\end{array}$ & $\begin{array}{l}\text { AED } \\
\left(\mathrm{mSv} \mathrm{y}^{-1}\right)\end{array}$ & References \\
\hline \multirow[t]{6}{*}{ cement } & SKA & 171 & 158 & 17.8 & [6] \\
\hline & Sudan & 202 & 379 & 5.68 & [7] \\
\hline & Iraq & 478 & 1000,3 & & {$[18]$} \\
\hline & Egypt & 185 & 239 & 2.34 & [19] \\
\hline & India & 422 & 336 & & [20] \\
\hline & Yemen & 70,9 & 49.6 & 1.99 & Present work \\
\hline \multirow[t]{4}{*}{ Gypsum } & KSA & 163.6 & 151.4 & 16.9 & [6] \\
\hline & Libya & 381 & 289 & 34.2 & [21] \\
\hline & Egypt & 69.9 & 90,18 & 0.65 & [19] \\
\hline & Yemen & 77.8 & 54 & 2.19 & Present work \\
\hline \multirow[t]{5}{*}{ Red Brick } & KSA & 39.5 & 34.1 & 3.8 & [6] \\
\hline & Libya & 442 & 123.7 & 14.6 & [21] \\
\hline & Sudan & 443 & 814 & 12.9 & [7] \\
\hline & Egypt & 152 & 197 & 1.92 & [19] \\
\hline & Yemen & 79 & 56 & 2.22 & Present work \\
\hline \multirow[t]{4}{*}{ Gravel } & KSA & 90 & 71.5 & 8.1 & [6] \\
\hline & Iraq & 894 & 2220 & & {$[18]$} \\
\hline & Egypt & 113 & 145 & 1.42 & [19] \\
\hline & Yemen & 525 & 376 & 14.77 & Present work \\
\hline \multirow[t]{5}{*}{ Marble } & KSA & 76.4 & 72.3 & 8.12 & [6] \\
\hline & Libya & 1452 & 1528 & 180 & [21] \\
\hline & Palestine & 356 & 646 & 8.9 & {$[22]$} \\
\hline & Egypt & 235 & 304 & 2.97 & [19] \\
\hline & Yemen & 510 & 362 & 14.3 & Present work \\
\hline
\end{tabular}

\section{5- CONCLUSION}

The sealed cup with SSNTD technique was used in measuring radon concentration, radium concentration and radon exhalation rates, the mass and the surface exhalation rates, the annual effective dose and alpha index. The values of radon concentrations were found to be less than the range of action levels from 200 to $600 \mathrm{~Bq} \mathrm{~m}^{-3}$ recommended by (ICRP, 1994). The values of radium concentration were found to be less than the permissible value of $370 \mathrm{~Bq} \mathrm{~kg}^{-1}$ as recommended by OECD and UNSCEAR. The values obtained for annual effective doses (AED) of the studied samples are less than the permissible value $\left(5 \mathrm{mSv} \mathrm{y}^{-1}\right)$. The radon exhalation in these samples was found to be below the average world value of $57600 \mathrm{mBq} \mathrm{m}^{-2} \mathrm{~h}^{-1}$. Hence it can be concluded that the study area is safe from the health hazard of radon concentration. It is possible to establish a data base for all building materials available in a local market using this technique with low cost for a large-scale nation-wide indoor radon screening measurement.

\section{REFERENCES}

1- A. M. O. Ismail, K.M. Abumurad, M.K. Kullab \& B.A. Al-Bataina, Measurement of Rn-222 Concentrations in Building Materials Used in Jordan, Second Arab Conference on the Peaceful Uses of Atomic Energy, Cairo 5 - 9 Nov, (1994).

2- Matiullah, A., Bashir, Kudo, K. \& Yang, X., Radon measurements in some houses of Tsukuba science city - Japan, Nucl. Tracks and Radiat. Meas., 22 (1993) 395-398.

3- ICRP, Lung cancer risks from indoor exposure to radon daughters. International Commission on Radiological Protection, Report 50, 17(1) (1970).

4- Douglas G. Brookins, The indoor radon problem. Columbian University press, New York, (1990). 5- International Commission on Radiological Protection (ICRP), Protection against Radon-222 at home and at work. ICRP Publication 65, Annals of the ICRP. Vol. 23, Oxford: Pergamon Press, (1993). 
6- Rafat M. Amin, A study of radon emitted from building materials using solid state nuclear track detectors, Journal of Radiation Research and Applied Sciences, 8 (2015) 516-522.

7- Abd-Elmoniem A. Elzain, Radon exhalation rates from some building materials used in Sudan, Indoor and Built Environment, 24(6) (2015) 852-860.

8- Eissa, M. F., Mostafa, R. M., Shahin, F., Hassan, K. F., \& Saleh, Z. A., Natural radioactivity of some Egyptian building materials. International Journal of Low Radiation, 5(1) (2008) 1-8.

9- International Commission on Radiological Protection, (ICRP). Lung cancer risk from indoor exposures to radon daughters. A report of a task group of the ICRP Publication 50. Oxford: Pergamon Press, 1987.

10- UNSCEAR, Sources and effects of ionizing radiation. Report to General Assembly, with Scientific Annexes. New York: United Nations (2000).

11- European Commission (EC), Radiation Protection Unit, Radiological protec- tion principles concerning the natural radioactivity of building materials. Radiation Protection, 112 (1999).

12- Nordic. Naturally occurring radiation in the Nordic countries recommendations. In The flag-book series. The Radiation Protection Authorities in Denmark, Finland, Iceland, Norway and Sweden, Reykjavik, (2000).

13- ICRP., Publication (65) protection against radon-222 at home and work. Barking, Essex: UK. Elsevier Science, Ltd, (1994).

14- OECD. Organization for Economic Co-operation Development, Exposure to radiation from the natural activity in building materials. Report by a Group of Experts of the OECD, Nuclear Energy Agency, Paris, (1979).

15- Singh, H., Singh, J., Singh, S., \& Bajwa, B. S., Radon exhalation rate and uranium estimation study of some soil and rock samples from Tusham ring complex, India using SSNTD technique. Radiation Measurements, 43 (2008) 459-462.

16- NCRP, National Council for Radiation Protection and Measurements, Ionizing Radiation Exposure of the Population of the United States. Report No. 93 (1987).

17- NCRP. National Council on Radiation Protection Measurements, Guidance for emergency response dosimetry. Report No. 179 (2017).

18- Sahar A. Amin, Measurements of radon exhalation rates in building materials used in Iraqi houses, Journal of Applied Sciences and Engineering Research, Vol. 4, Issue 4, ( 2015) 437-442.

19- Hesham A. Yousef, A. H. El-Farrash, A. Abu Ela \& Q. Merza, Determination Of Radon Concentrations In Some Building Materials Using Passive Technique, International Journal of Physics and Research (IJPR), Vol. 5, Issue 2, (Apr 2015) 35-46.

20- M. Nain , R.P. Chauhan \& S.K. Chakarvarti, Alpha radioactivity in Indian cement samples, Iran. J. Radiat. Res., 3 (4): (2006) 171-176.

21- A.F. Saad, Hend H. Al-Awami \& N.A. Hussein, Radon exhalation from building materials used in Libya, Radiation Physics and Chemistry, 101 (2014) 15-19.

22- F. Shoqwara, N. Dwaikat \& G. Saffarini, Measurement of Radon Exhalation Rate from Building Materials, Research \& Reviews: Journal of Physics, 2(1) (2013). 